\title{
Autoimmune reaction to a liver specific membrane antigen during acute viral hepatitis
}

\author{
A. M. G. COCHRANE, A. MOUSSOUROS, A. SMITH, A. D. THOMSON, \\ A. L. W. F. EDDLESTON, AND ROGER WILLIAMS
}

From the Liver Unit, King's College Hospital and Medical School, London

SUMMARY Lymphocyte cytotoxicity for isolated hepatocytes has been demonstrated in $93 \%$ of cases of acute viral hepatitis tested within two weeks of the onset of symptoms. The frequency of cytotoxicity during this time was similar for $\mathrm{HBsAg}$ positive and negative cases. However, after this time it was significantly higher in $\mathrm{HBsAg}$ positive than negative cases, $90 \%$ and $25 \%$ respectively $(\mathbf{P}<0.01)$. Cytotoxicity was found in B-cell, but not T-cell, enriched fractions of lymphocytes, compatible with an antibody-dependent $\mathrm{K}$-cell mediated reaction. In two cases the assay remained positive on retesting six months later, and follow-up liver biopsies showed the features of chronic aggressive hepatitis. These findings suggest that, in addition to the known immunological reactions against viral antigens that occur during the acute phase of viral hepatitis, an autoimmune reaction directed against a liver specific protein is also initiated; and if this reaction persists then chronic hepatitis may develop.

Recent studies using the lymphocyte transformation (Laiwah, 1971) and leucocyte migration tests (Irwin et al., 1974; Reed et al., 1974) have shown that sensitization to the hepatitis B surface antigen can be detected in the majority of cases of antigen positive hepatitis. This, together with the recent demonstration of HBsAg on the surface of hepatocytes during acute hepatitis B infection (Alberti et al., 1975), supports the concept that a T-cell mediated immune reaction directed against virus bearing hepatocytes is responsible for the liver damage (Dudley et al., 1972).

In addition to destroying infected hepatocytes, we have suggested that this T-lymphocyte response could lead to the activation of $B$ cells responsive to a normal hepatocyte surface antigen, the liver-specific membrane lipoprotein (Eddleston and Williams, 1974). With removal of the infected liver cells the stimulus to this B-cell activation would disappear but if, for some reason, the virus persists or if there is a genetic defect in the control of immune responses then continuation of the reaction could be the mechanism underlying progression to chronic liver disease. To investigate this possibility further we have studied lymphocyte cytotoxicity for isolated hepatocytes both in patients with HBsAg positive and negative acute viral hepatitis.

Received for publication 14 June 1976

\section{Methods}

Of the 36 patients investigated, 18 (10 males and eight females) were $\mathrm{HBsAg}$ positive, the remainder (six males and 12 females) being $\mathrm{HBsAg}$ negativeboth initially and throughout the course of the illness. All patients had been admitted to hospital, although the timing of the admission from the onset of symptoms, the severity of the illness, and the degree of abnormality in liver function tests varied (Table). In eight patients the course was that of a fulminant hepatitis with the development of encephalopathy, and six of these died. Serum levels of bilirubin, aspartate aminotransferase, alkaline phosphatase, smooth muscle antibody, and antinuclear factor were also measured on the day of cytotoxicity testing. Liver biopsies performed during the acute illness in 21 of the patients were assessed 'blind' by a pathologist, for features of liver cell necrosis and cellular infiltration, each graded on a point scoring system from zero to nine, to give an index of the severity of liver damage. Twenty-eight of the patients were investigated only once, but cytotoxicity in the other eight cases was measured both during the acute state and again after an interval of three to six months.

PREPARATION OF LYMPHOCYTES

Leucocyte-rich plasma was obtained from $20 \mathrm{ml}$ 
Table Clinical details of the patients studied

\begin{tabular}{|c|c|c|c|c|c|c|c|c|c|c|}
\hline \multirow[t]{2}{*}{ Case no. and sex } & \multirow{2}{*}{$\begin{array}{l}\text { Weeks } \\
\text { from } \\
\text { onset }\end{array}$} & \multirow{2}{*}{$\begin{array}{l}\text { Cyto- } \\
\text { toxicity }\end{array}$} & \multirow{2}{*}{$\begin{array}{l}\text { Aspartate } \\
\text { trans- } \\
\text { aminase } \\
A S T \\
(I U \mid D)\end{array}$} & \multirow{2}{*}{$\begin{array}{l}\text { Bilirubin } \\
\text { bili } \\
\text { (Amol/l) }\end{array}$} & \multirow{2}{*}{$\begin{array}{l}\text { Alkaline } \\
\text { phospha- } \\
\text { tase } \\
\text { AP } \\
(I U / I)\end{array}$} & \multirow[t]{2}{*}{$H B s A g$} & \multicolumn{2}{|c|}{ Autoantibodies } & \multirow{2}{*}{$\begin{array}{l}\text { Hepato- } \\
\text { cyte } \\
\text { necrosis }\end{array}$} & \multirow{2}{*}{$\begin{array}{l}\text { Cellular } \\
\text { infiltrate } \\
\mathrm{t}\end{array}$} \\
\hline & & & & & & & $A N A$ & $S M A$ & & \\
\hline $1 \mathbf{M}$ & 1 & 39 & 350 & 80 & - & + & NT & NT & & \\
\hline $2 \mathrm{M}$ & 1 & 48 & 500 & 120 & - & - & NT & NT & & \\
\hline $3 \mathrm{~F}$ & 1 & 49 & 730 & 90 & 89 & + & - & - & 6 & 4 \\
\hline $5 \mathrm{~F}$ & 1 & 45 & 320 & 400 & 204 & - & - & - & 6 & 2 \\
\hline $6 \mathrm{~F}$ & 1 & 71 & 232 & 420 & 245 & - & - & - & 6 & 7 \\
\hline $7 \mathrm{M}$ & 2 & 25 & 450 & 275 & - & - & $\overline{1}$ & $\overline{1}$ & & \\
\hline $8 \mathrm{M}$ & 2 & 34 & 300 & 180 & 204 & - & NT & NT & & \\
\hline $9 \mathrm{M}$ & 2 & 36 & - & - & - & + & NT & NT & & \\
\hline $10 \mathrm{~F}$ & 2 & 48 & 98 & 270 & 118 & + & - & - & 5 & 3 \\
\hline $11 \mathrm{M}$ & 2 & 60 & 1800 & 232 & 139 & + & - & 10 & 6 & 5 \\
\hline $12 \mathrm{M}$ & 2 & 74 & 1600 & 190 & 210 & + & - & - & & \\
\hline $13 \mathrm{~F}$ & 2 & 66 & 380 & 610 & 1000 & - & - & - & 6 & 5 \\
\hline $15 \mathrm{~F}$ & 3 & 0 & 360 & 336 & 100 & - & 10 & 10 & & \\
\hline $16 \mathrm{M}$ & 3 & 45 & 1900 & 210 & 51 & + & - & - & & \\
\hline $17 \mathrm{~F}$ & 3 & 63 & 107 & 395 & 207 & - & - & - & & \\
\hline $18 \mathrm{~F}$ & 4 & 0 & 1100 & 312 & 217 & $\mathbf{A b}$ & 40 & 40 & 7 & 7 \\
\hline $19 \mathrm{~F}$ & 4 & 6 & 1500 & 227 & 32 & - & - & 320 & 9 & 7 \\
\hline $20 \mathrm{~F}$ & 4 & 9 & 53 & 148 & 139 & $\mathbf{A} \mathbf{b}$ & - & 320 & 6 & 2 \\
\hline $21 \mathrm{~F}$ & 4 & 30 & 206 & 390 & 106 & - & - & 40 & 9 & 3 \\
\hline $22 \mathrm{~F}$ & 5 & 8 & 248 & 187 & 105 & - & 10 & - & 7 & 3 \\
\hline $23 \mathrm{M}$ & 6 & 60 & 255 & 96 & 87 & + & - & - & & \\
\hline $24 M$ & 6 & 79 & 184 & 180 & 355 & - & - & - & 5 & 3 \\
\hline $25 \mathrm{~F}$ & 6 & 13 & 147 & 460 & 241 & - & - & - & 6 & 5 \\
\hline $26 \mathrm{~F}$ & 6 & 32 & 216 & 65 & 115 & + & - & 10 & 8 & 7 \\
\hline $27 \mathrm{~F}$ & 6 & 36 & 1450 & 49 & 610 & + & 120 & - & 4 & 3 \\
\hline $28 \mathrm{M}$ & 6 & 43 & 57 & 60 & 109 & + & - & 10 & 5 & 3 \\
\hline $29 \mathrm{~F}$ & 8 & 16 & 246 & 95 & 118 & - & 10 & - & 7 & 2 \\
\hline $30 \mathrm{~F}$ & 8 & 31 & 243 & 127 & 278 & - & 1280 & 80 & 6 & 5 \\
\hline $31 \mathrm{~F}$ & 8 & 67 & 65 & 7 & 37 & + & 20 & - & 1 & 2 \\
\hline $32 \mathrm{M}$ & 8 & 34 & 350 & 40 & 168 & + & - & 20 & 6 & 2 \\
\hline $35 \mathrm{~F}$ & 8 & 5 & 380 & 370 & 272 & + & - & - & & \\
\hline $36 \mathrm{M}$ & 8 & 54 & 1100 & 281 & 79 & + & - & - & & \\
\hline
\end{tabular}

Ab: HBs antibody. NT: Not tested

peripheral venous blood by sedimentation with $2 \mathrm{ml}$ $6 \%$ Dextran and 100 units preservative-free heparin. After diluting 1:1 with RPMI 1640, the plasma was incubated in a cotton-wool column at $37^{\circ} \mathrm{C}$ for 15 minutes to remove macrophages (Rocklin et al., 1970). The resulting leucocytes were centrifuged over a Ficoll Triosil density gradient to remove the remaining neutrophils and red blood cells (Böyum, 1968). The interface lymphocytes which contained less than $1 \%$ neutrophils and $5 \%$ monocytes were used for cytotoxicity testing.

In some patients enriched populations of $B$ and $T$ lymphocytes were prepared. The method of separation has been described in detail elsewhere (Cochrane et al., 1976). It entailed rosetting T-cells with sheep red blood cells, and B cells with sheep red cells coated with antibody and complement, followed by separation of the rosetted from non-rosetted cells by centrifugation over a Ficoll Triosil density gradient.
MICROCYTOTOXICITY ASSAY

This was carried out as described elsewhere (Thomson et al., 1974) except that the enzyme solution for the preparation of isolated hepatocytes did not contain deoxyribonuclease. A suspension of lymphocytes in RPMI 1640, containing 1 Molar Hepes $2.3 \%$, foetal calf serum $10 \%$, penicillin 200 units per $\mathrm{ml}$, and streptomycin $100 \mu \mathrm{g} / \mathrm{ml}$ was added to the hepatocytes in microtest plates to give a final ratio of $400: 1$. After 48 hours of incubation at $37^{\circ} \mathrm{C}$ plates were inverted for two hours and detached hepatocytes and lymphocytes were removed by gentle washing. The number of hepatocytes remaining in the test compared with control wells was expressed as the per cent cytotoxicity. Each plate, consisting of six rows of 10 wells each, had 20 control wells and each test suspension of lymphocytes was added to at least 10 wells.

The upper limit of normal for cytotoxicity in this 
assay was $32 \%$, this being two standard deviations above the mean value of $4 \%$ obtained in 25 healthy control subjects.

\section{Results}

Significant cytotoxicity for isolated hepatocytes was demonstrated in $13(93 \%)$ of the 14 patients tested within two weeks from the onset of their illness (Fig. 1). These included all of the six cases who were positive for HBsAg at this time and seven of the eight who were not. Of the 22 patients tested between three and eight weeks after admission, cytotoxicity was present in $12(55 \%)$ including nine $(90 \%)$ of the 10 who were $\mathrm{HBsAg}$ positive, but only three $(25 \%)$ of the 12 who were antigen negative $(P<0.01$, Chi squared test).

Enriched populations of $B$ and $T$ lymphocytes were prepared from five patients, three HBsAg negative and two $\mathrm{HBsAg}$ positive, whose peri-

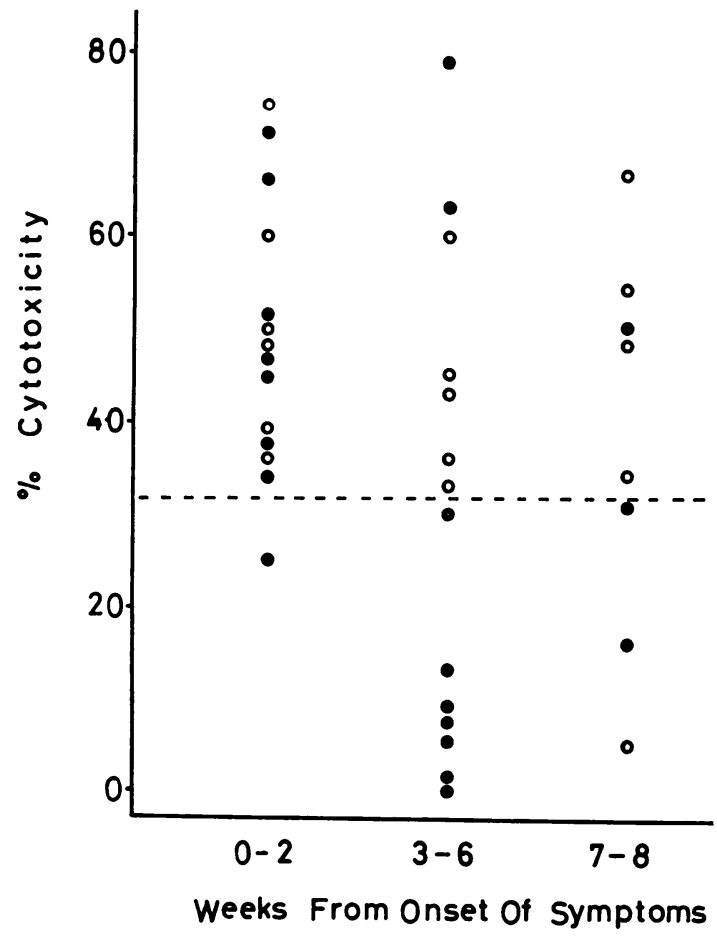

Fig. 1 Lymphocyte cytotoxicity for isolated hepatocytes in patients with $\mathrm{HBs} A \mathrm{~g}$ positive $(\mathrm{O})$ and HBs Ag negative (O) acute viral hepatitis separated according to time of initial measurement in relation to onset of symptoms. The horizontal dotted line indicates the upper limit of the normal range. pheral blood lymphocytes showed significant cytotoxicity (mean $42 \% \pm 8$ ). When B-cell enriched fractions were tested, cytotoxicity was present in all five cases, mean $49 \% \pm 6$. In contrast, when T-cell enriched fractions were used, the results were all within the normal range (mean $14 \% \pm 13$ ) (Fig. 2). In five further patients, whose peripheral blood lymphocytes did not show significant cytotoxicity, the results obtained using B-cell and T-cell enriched populations $(4 \% \pm 8$ and $5 \% \pm 9$ respectively) were not significantly different from those obtained using the combination of $\mathrm{T}$ and $\mathrm{B}$ lymphocytes $(12 \%$ $\pm 8)$.

There was no correlation between the presence or absence of cytotoxicity and the levels of serum aspartate aminotransferase, bilirubin, or alkaline phosphatase, measured on the day of testing. Neither was there a correlation between the presence of cytotoxicity and the histological features of liver cell necrosis nor the degree of lymphocyte, plasma cell, and monocyte infiltration, in the 21 patients in whom a liver biopsy was performed within two weeks of testing.

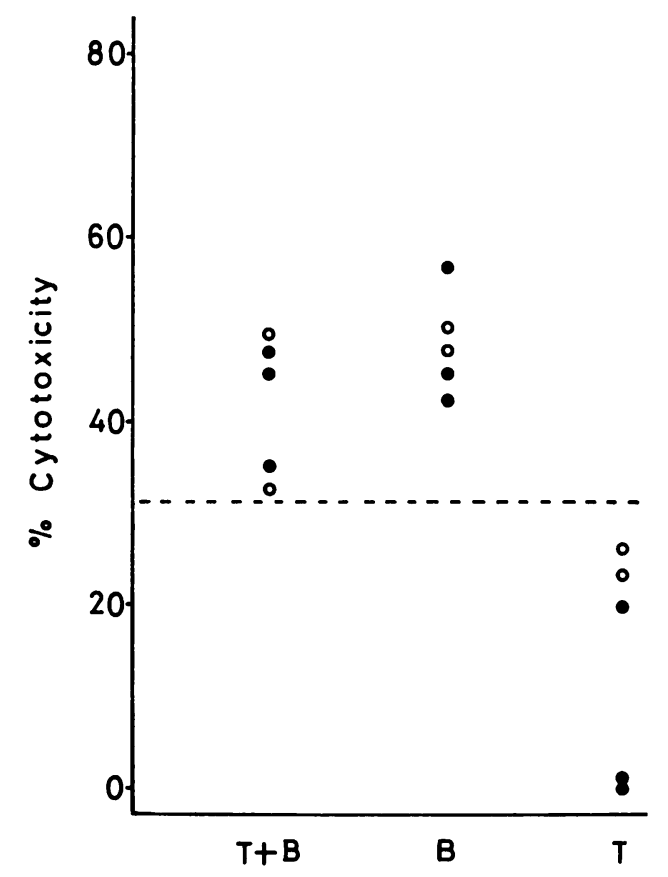

Fig. 2 Cytotoxicity obtained using peripheral blood lymphocytes, $T$ and $B, B$ cell enriched, and $T$ cell enriched fractions of lymphocytes, in six of the patients. $\mathrm{HBs} \mathrm{Ag}$ positive $(\mathrm{O})$ and $\mathrm{HBs} \mathrm{Ag}$ negative $(O)$ cases. 


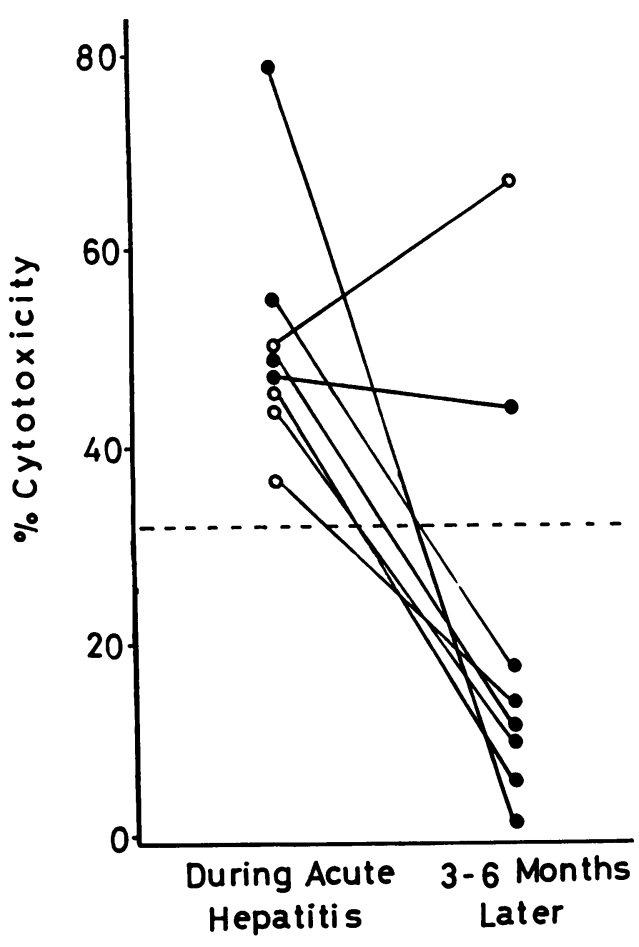

Fig. 3 Results of the cytotoxicity assay in eight patients during the acute phase of viral hepatitis and on repeat testing three to six months later. $\mathrm{HBs} A \mathrm{~g}$ positive (O) $\mathrm{HBs} \mathrm{Ag}$ negative (O).

In two patients, one HBsAg positive and one negative, the acute hepatitis progressed to chronic active hepatitis. Both showed significant cytotoxicity when first tested during their acute illness, and on repeat testing six months later both again gave positive results (Fig. 3). A further biopsy in each case showed chronic inflammatory cell infiltration of portal tracts and piecemeal necrosis of periportal hepatocytes typical of chronic aggressive hepatitis. Six further cases, all of whom showed cytotoxicity during their acute illness, have so far been retested three to six months later, but in these cytotoxicity results were now within the normal range. Tests for HBsAg, which were initially positive in four of the cases, were all negative, and liver function tests had returned to normal.

\section{Discussion}

In recent studies using this assay of lymphocytemediated cytotoxicity for hepatocytes we have found consistently positive results in patients with un- treated chronic active hepatitis. The reaction appears to be mediated by cells bearing Fc-receptors (Kcells) (Cochrane et al., 1976), and can be blocked by the addition of small amounts of a purified liver specific membrane lipoprotein prepared from either rabbit or human liver, suggesting that the hepatocyte damage is due to an immunological reaction directed specifically at this antigen (Thomson et al., 1974).

The present study demonstrates that a similar autoimmune response occurs in the majority of patients during the early stages of acute viral hepatitis. This reaction in both antigen positive and negative cases is clearly not due to autoreactive Tcells but is more likely to be of the antibodydependent cell-mediated type as in the patients with chronic active hepatitis. If this autoimmune reaction is due to activation of B lymphocytes by T-cells reacting with viral determinants on the hepatocyte membrane then it is possible to envisage two ways in which the reaction could continue and so produce chronic active hepatitis (Eddleston and Williams, 1974). Firstly, there might be an inability to suppress the autoreactive B-cells even though the virus had been cleared, and we have recently shown that the histocompatibility antigens HLA-B8 and HLA-B12 in patients with $\mathrm{HBsAg}$ negative chronic active hepatitis seem to be closely linked to genes promoting such an immune hyper-responsiveness (Galbraith et al., 1976). Secondly, if the viral stimulus remains, continued T-cell destruction of infected hepatocytes will constantly stimulate the autoreactive B lymphocytes. This may have been the situation in the one patient who remained HBsAg positive after six months. He continued to show lymphocyte-mediated cytotoxicity for hepatocytes and had gone on to develop chronic active hepatitis. The other patient who developed this condition also showed persistence of the cytotoxic reaction but was HBsAg negative throughout, supporting recent reports of chronic liver disease occasionally after HBsAg negative acute hepatitis (Alter et al., 1975; Galbraith et al., 1975).

The absence of a correlation between cytotoxicity and the various clinical estimates of the degree of liver damage during the acute illness suggests that the autoimmune reaction to the liverspecific protein plays a minor role in the production of hepatocellular necrosis at this stage. However, the finding of liver lesions, resembling those found in chronic active hepatitis, in rabbits repeatedly immunized with liver-specific antigen (Meyer zum Büschenfelde et al., 1972), some of which show progression to cirrhosis (Meyer zum Büschenfelde et al., 1974), clearly shows that persistence of sensitization to the membrane lipoprotein could be responsible 
for the development of chronic active hepatitis in man.

We are grateful to the Wellcome Trust for their continued support and to Dr Bernard Portmann for his assessment of the liver biopsies.

\section{References}

Alberti, A., Realdi, G., Tremolada, F., and Cadrobbi, P. (1975). HBAg on liver-cell surface in viral hepatitis (letter). Lancet, 1, 346.

Alter, H. J., Purcell, R. H., Holland, P. V., Feinstone, S. M., Morrow, A. G., and Moritsugu, Y. (1975). Clinical and serological analysis of transfusion-associated hepatitis. Lancet, 2, 838-841.

Böyum, A. (1968). Isolation of leucocytes from human blood. Scandinavian Journal of Clinical and Laboratory Investigation, 21, Suppl. 97, 9-29.

Cochrane, A. M. G., Moussouros, A., Thomson, A. D., Eddleston, A. L. W. F., and Williams, R. (1976). Antibody-dependent cell mediated ( $\mathrm{K}$ cell) cytotoxicity against isolated hepatocytes in chronic active hepatitis. Lancet, $\mathbf{1}$, 441-444.

Dudley, F. J., Fox, R. A., and Sherlock, S. (1972). Cellular immunity and hepatitis-associated, Australia antigen liver disease. Lancet, 1, 723-726.

Eddleston, A. L. W. F., and Williams, R. (1974). Inadequate antibody response to HBAg or suppressor T-cell defect in development of active chronic hepatitis. Lancet, 2, 15431545.

Galbraith, R. M., Eddleston, A. L. W. F., Williams, R., Webster, A. D. B., Pattison, J., Doniach, D., Kennedy,
L. A., and Bachelor, J. R. (1976). Enhanced antibody responses in active chronic hepatitis: relation to HLA-B8 and B12 and portosystemic shunting. Lancet, 1, 930-934.

Galbraith, R. M., Portmann, B., Eddleston, A. L. W. F., Williams, R., and Gower, P. E. (1975). Chronic liver disease developing after outbreak of HBsAg-negative hepatitis in haemodialysis unit. Lancet, 2, 886-890.

Irwin, G. R., Jr., Hierholzer, W. J., Jr., Cimis, R., and McCollum, R. W. (1974). Delayed hypersensitivity in hepatitis B: clinical correlates of in vitro production of migration inhibition factor. Journal of Infectious Diseases, 130, 580.

Laiwah, A. A. C. Y. (1971). Lymphocyte transformation by Australia antigen. Lancet, 2, 470-471.

Meyer zum Büschenfelde, K. H., and Hopf, U. (1974). Studies on the pathogenesis of experimental chronic active hepatitis in rabbits: I. Induction of the disease and protective effect of allogeneic liver-specific proteins. British Journal of Experimental Pathology, 55, 498-508.

Meyer zum Büschenfelde, K. H., Kössling, F. K., and Miescher, P. A. (1972). Experimental chronic active hepatitis in rabbits following immunization with human, liver proteins. Clinical and Experimental Immunology, 11, 99-108.

Reed, W. D., Eddleston, A. L. W. F., and Williams, R. (1974). Immunopathology of viral hepatitis in man. Progress in Medical Virology, 17, 38-76.

Rocklin, R. E., Meyer, O. L., and David, J. R. (1970). An in vitro assay for cellular hypersensitivity in man. Journal of Immunology, 104, 95.

Thomson, A. D., Cochrane, A. M. G., McFarlane, I. G., Eddleston, A. L. W. F., and Williams, R. (1974). Lymphocyte cytotoxicity to isolated hepatocytes in chronic active hepatitis. Nature, 252, 721-722. 